\title{
Novelties in the field of treatment of Vitiligo: DHA, caramel and Rattany that acts even as UV screen
}

\author{
Piotr Brzezinski ${ }^{1}$, Lorenzo Martin²
}

${ }^{1}$ Institute of Biology and Environmental Protection, Pomeranian Academy, Slupsk, Poland, ${ }^{2}$ University of Siena, Department of Pharmaceutical Biotechnologies, Via A. Moro 2, 53100 Siena, Italy

Corresponding author: Lorenzo Martini, E-mail: martinil163@libero.it

\begin{abstract}
In this study we propose a gélée made of DHA, Rattany and caramel to attempt to defeat Vitiligo (at diverse percentage of depigmentation of the whole body) in 9 volunteers. The revolutionary approach is that we had previously treated the same 9 volunteers using the single ingredient (idest: only DHA, only Rattany, only caramel) for an entire month, before to treat them with the gélée we had created. We have observed that time of remission was one month for all the 9 cases. One volunteer was a black woman: her results were really amazing.
\end{abstract}

Key words: Vitiligo; DHA, Rattany; Caramel; Self tanning products

Vitiligo is a long-term skin condition characterized by patches of the skin losing their pigment. The patches of skin affected become white and usually have sharp margins [1]. Generally the patches begin on areas of skin that are exposed to the sun. It is more noticeable in people with dark skin [2]. Vitiligo may result in psychological stress and those affected are often stigmatized [3].

The exact cause of vitiligo is unknown $[1,4]$. It is believed to be due to genetic susceptibility that is surely evoked by an environmental factor such an autoimmune disease $[1,2,5]$. All this yields to the destruction of skin pigment cells. Risk factors include a family history of the condition or other autoimmune diseases, such as hyperthyroidism, alopecia areata, and pernicious anemia [2]. It is not contagious. There is no known cure for vitiligo. For those with light skin, sunscreen and makeup are all that is typically recommended. Another treatment is phototherapy to darken the light patches $[1,6]$. Alternatively, efforts to lighten the unaffected skin, such as with hydroquinone or methylhydroquinone, may be tried especially in black people [2]. Globally about $1 \%$ of people are affected by vitiligo. In India and circumstant lands people affected by vitiligo show rates as high as $2-3 \%[7,8]$. Vitiligo has been described since ancient history [1,9].

Too often vitiligo may be mistaken for other malaises as: Pityriasis alba; Tuberculoid leprosy; Tinea versicolor; Albinism; Piebalism (the syndrome of the bald eagle); Progressive macular hypomelanosis; Primary adrenal insufficiency [10-11].

The efficacy of Dihydroxiacetone (DHA) was discovered in early 50 s of XX century in Germany, when it was administered as artificial sugar to diabetic children.

Effectively too many young patients could not bear the disgustful flavor of the synthetic sugar, regorged it and just puked their skin resulted dark and hyperpigmented.

In 60s DHA began to appear in manifold cosmetic items for self tanning, even skin showed a vermilion nuance and even the artificial tanning (camouflage) was never uniform and homogenous and then its employ was progressively abandoned at all.

In this study we want to propose a gélée made of: Dha; Krameria Triandra Root Extract; Caramel.

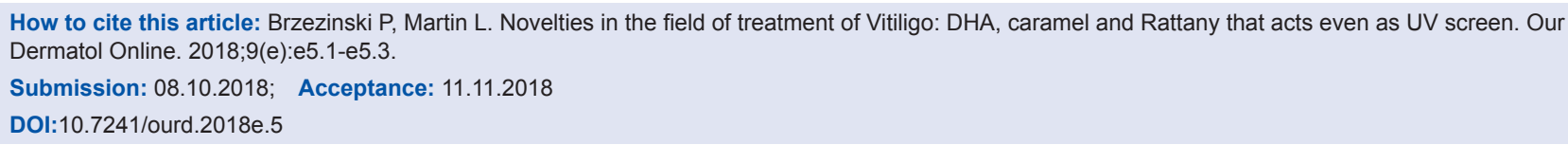


Rhatany (or rattany), plant native to Perù' and other countries of Latin America is extremely rich in antraquinones as emodin and chrysophanol that reveal a magnificent sunscreen activity especially against UVB rays.

The biological action of rhatany is caused by the astringent rhataniatannic acid, which is similar to tannic acid. Infusions have been used as a gargle, a lozenge, especially when mixed with cocaine as a local hemostatic and remedy for diarrhea [12]. When finely powdered, the dried roots furnished a frequent constituent of tooth powders. The powdered roots have also served, especially in Portugal, to color wines ruby red. The root bark contains an almost insoluble free red substance called ratanhia red.

Caramel is a typical routinary ingredient for manifold self tanning cosmetics all other the world, but it is always employed alone with no other ingredient which may reveal self tanning function.

It does not bespeaks satisfactory and repicable results, even in the same person's skin.

\section{MATERIALS AND METHODS}

Our experience is based on the treatment of 9 (a,b,c,d,e,f,g,h,i) volunteers suffering from Vitiligo, at diverse percentages of incidence, till $30 \%$ of depigmentation of the whole body, treating:

A,b,c with only DHA

D,e,f with only Krameria triandra

\section{G,h,I with only Caramel}

For an entire month of cure.

It must be considered that Case $\mathrm{G}$ is a black woman, and this undoubtedly plays a role in the experimentation.

After this previous treatment, all of them were prayed to use our combinaison:

DHA, Rattany and caramel together.

And we have recorded and thus plotted all the times of remission of the single cases.

We kept on account the \% of depigmentation, in order to be more scrupulous.

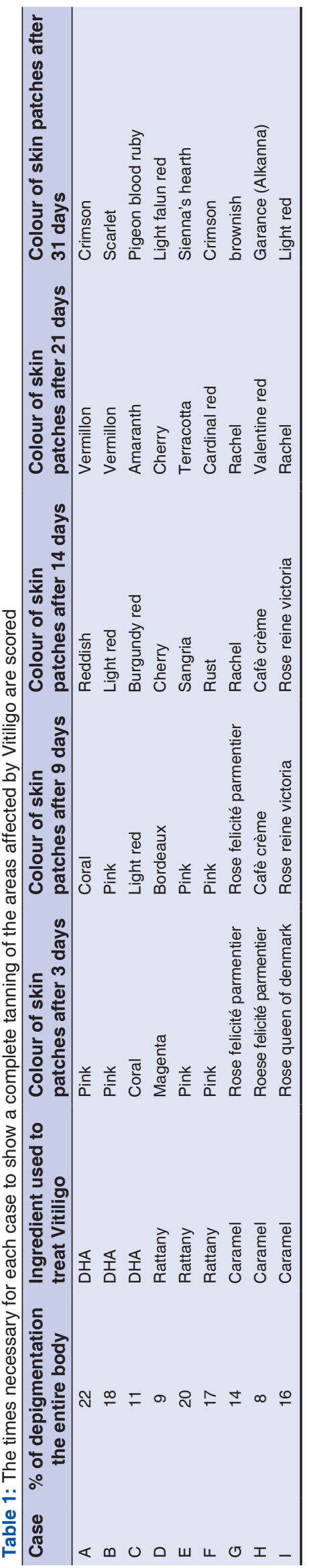


Table 2: The colour the depigmented areas of the body assume at $3^{\text {rd }}, 9^{\text {th }}, 14^{\text {th }}, 21^{\text {th }}, 31^{\text {th }}$ days, administering our combinaison of DHA, Rattany and caramel

\begin{tabular}{|c|c|c|c|c|c|}
\hline Case & $\begin{array}{l}\text { Colour of skin } \\
\text { patches after } 3 \text { days }\end{array}$ & $\begin{array}{l}\text { Colour of skin } \\
\text { patches after } 9 \text { days }\end{array}$ & $\begin{array}{l}\text { Colour of skin } \\
\text { patches after } 14 \text { days }\end{array}$ & $\begin{array}{l}\text { Colour of skin patches } \\
\text { after } 21 \text { days }\end{array}$ & $\begin{array}{l}\text { Colour of skin patches } \\
\text { after } 31 \text { days }\end{array}$ \\
\hline$A$ & Pink & Rachel & Marc' spirit & Flesh color & Flesh color \\
\hline B & Rachel & Rachel & Rachel & Shocking pink & Flesh color \\
\hline C & Cherry & Cherry & Marc'spirit & Flesh color & Flesh color \\
\hline D & Vermilion & Vermilion & Marc'spirit & Flesh color & Flesh color \\
\hline$E$ & Pink & Shocking pink & Flesh color & Flesh color & Flesh color \\
\hline $\mathrm{F}$ & Pink & Pink & Pink & Rachel & Flesh color \\
\hline G & Rose tea & Rose tea & Vermillon & Brown & Dark brown \\
\hline $\mathrm{H}$ & Rose felicité parmentier & Rose felicité parmentier & Vermilion & Light red & Flesh color \\
\hline I & Pink & Pink & Pink & Rose bourbon & Flesh color \\
\hline
\end{tabular}

We prayed the volunteers to expose to summer sun rays almost one hour pro day at the same hour, that is at midday, when UVA, UVB, UVC and IR rays are concomitant (as we have stressed before Krameria trianda root extract exhibits a noticeable action against harmful sun rays).

\section{RESULTS}

In Table 1 the times necessary for each Case to show a complete tanning of the areas affected by Vitiligo are scored, when all volunteers were treated with: Only DHA; Only Rattany; Only Caramel. The colour the depigmented areas of the body was presented in table 2.

\section{CONCLUSION}

It is suggestive to notice that the volunteers presenting a high percentage of depigmentation, show a slower decrease of pigmentation using our combinaison (A,E,I).

In the volunteers who show a lower percentage of depigmentation, we have stated the depigmentation begins at the $3^{\text {rd }}$ and it is faster day after day.

In any case a flesh color is always reached in all cases at the end of treatment (generally after the $27^{\text {th }}$ day of cure).

Case $\mathrm{G}$ is very intriguing, as since the very first days patches assume a pinkish color, growing dark brown at the end of the month of treatment.

Black people, we could assert, are more amenable to our self tanning combinaison.

\section{Statement of Human and Animal Rights}

All procedures followed were in accordance with the ethical standards of the responsible committee on human experimentation (institutional and national) and with the Helsinki Declaration of 1975, as revised in 2008.

\section{Statement of Informed Consent}

Informed consent was obtained from all patients for being included in the study.

\section{REFERENCES}

1. Oripelaye MM, Olasode OA, Onayemi O, Olanrewaju OF. Familial vitiligo in mother and child; the genetic theory connection. Our Dermatol Online. 2017;8:174-6.

2. Questions and Answers about Vitiligo. NIAMS. June 2014. Archived from the original on 21 August 2016. Retrieved 11 August 2016.

3. Oripelaye MM, Onayemi O, Olasode OA, Olanrewaju FO. Vitiligo on tribal mark: A demostration of Wolf's isotopic response. Our Dermatol Online. 2017;9:48-50.

4. Chiriac A, Foia L, Miron C. Vitiligo - Anti-thyroid peroxidase antibody. Our Dermatol Online. 2012;3:232-3.

5. Borowska K. How narrow-band and broad-band uvb irradiation influences the histomorphology evaluations of experimental animals' skin - a comparative study. Part I. Our Dermatol Online. 2017;8(3e):e5.

6. Kasumagic-Halilovic E, Ovcina-Kurtovic N, Helppikangas H. Anti-thyroglobulin Antibody and Vitiligo: A controlled study. Our Dermatol Online. 2015;6:145-8.

7. Krüger C, Schallreuter KU. A review of the worldwide prevalence of vitiligo in children/adolescents and adults. Int J Dermatol. 2012;51:1206-12.

8. Lahlou A, Baybay H, Gallouj S, Mernissi FZ. Childhood vitiligo: Clinical epidemiological profile. Our Dermatol Online. 2017;8:264-7.

9. Arif T, Hassan I, Nisa N. Morphea and vitiligo-A very uncommon association. Our Dermatol Online. 2015;6:232-4.

10. Zonunsanga. Atypical pityriasis versicolor: case report. Our Dermatol Online. 2015;6:198-200.

11. Van Geel N, Mollet I, Brochez L, Dutré M, De Schepper S, Verhaeghe E, et al. New insights in segmental vitiligo: case report and review of theories. Br J Dermatol. 2012;166:240-6.

12. Hugh C. "Rhatany". Encyclopædia Britannica. 1911;7 (11 ${ }^{\text {th }}$ ed.). Cambridge University Press. p. 231.

Copyright by Piotr Brzezinski, et al. This is an open-access article distributed under the terms of the Creative Commons Attribution License, which permits unrestricted use, distribution, and reproduction in any medium, provided the original author and source are credited.

Source of Support: Nil, Conflict of Interest: None declared. 